\title{
Mind your own business: technologies for governing social worker subjects
}

\section{Marcus Lauri}

To cite this article: Marcus Lauri (2018): Mind your own business: technologies for governing social worker subjects, European Journal of Social Work, DOI: 10.1080/13691457.2018.1529661

To link to this article: https://doi.org/10.1080/13691457.2018.1529661
(2) 2018 The Author(s). Published by Informa UK Limited, trading as Taylor \& Francis Group
曲 Published online: 05 Oct 2018.
Submit your article to this journal $\widetilde{ }$

凹 Article views: 65

View Crossmark data 


\title{
Mind your own business: technologies for governing social worker subjects
}

\section{Sköt dig själv: teknologier för styrning av socialarbetarsubjekt}

\author{
Marcus Lauri (D) \\ Department of Social Work, Mid Sweden University, Östersund, Sweden
}

\begin{abstract}
A vast body of research has demonstrated negative effects on social work following from a neoliberalisation of the welfare state. This article explores some of the ways in which such neoliberalisation may be carried out and maintained, by shaping social workers subjects in ways that make them compliant in such a scheme. From interviews with social workers in Sweden, an analysis of budget governing, individual wage negotiations, the client contractor model and social worker supervision shows that such governing technologies may accentuate an individual, competitive and detached subject. This may in turn produce loyalty to individual selves and management, which risks undermining the formation of a social worker subject who is willing to stand shoulder to shoulder with both their co-workers and their clients.
\end{abstract}

\begin{abstract}
ABSTRAKT
Omfattande forskning har visat hur nyliberaliseringen av välfärdsstaten fått negativa effekter. Denna artikel undersöker olika sätt som gör att socialarbetare formas för att göra dem medgörliga i en sådan omdaning. Genom intervjuer med socialarbetare i Sverige analyseras hur budgetstyrning, individuell lönesättning, beställar-utförarmodellen och socialarbetares handledning kan bidra till att skapa en individualistisk, konkurrensinriktad och likgiltig socialarbetare. Detta kan i sin tur skapa lojalitet med självet och ledningen vilket riskerar att underminera ett socialarbetarsubjekt som står på klientens och sina medarbetares sida.
\end{abstract}

\section{KEYWORDS}

Social work; neoliberalism; subject formation; governmentality; assemblage

\section{NYCKELORD}

socialt arbete; nyliberalism; subjektsformering; styrning; styrningsmentalitet

\section{Introduction}

The effects on human life stemming from the last few decades of neoliberalism have been investigated in a wide variety of social science research that illustrates how welfare services such as social work have been subjected to rationalisation, standardisation and austerity. While standardisation, specialisation and other practices associated with the contemporary organisation of social work may have their benefits, several studies show that the recent decades of neoliberal welfarestate reorganisation have resulted in serious limitations for social work and suffering for both clients and social workers (cf. Kamali \& Jönsson, 2018). While research that highlights the effects for social workers - like a faster pace of work, stress and alienation - is important, I argue that we must also look beyond these effects and focus on how such a transformation may be carried out

CONTACT Marcus Lauri $\otimes$ marcus.lauri@miun.se Department of Social Work, Mid Sweden University, Östersund 831 40, Sweden

(c) 2018 The Author(s). Published by Informa UK Limited, trading as Taylor \& Francis Group

This is an Open Access article distributed under the terms of the Creative Commons Attribution-NonCommercial-NoDerivatives License (http:// creativecommons.org/licenses/by-nc-nd/4.0/), which permits non-commercial re-use, distribution, and reproduction in any medium, provided the original work is properly cited, and is not altered, transformed, or built upon in any way. 
and maintained (Oksala, 2013, p. 39). If the question of 'how' is not analysed, it is likely that resisting and changing such developments will prove more difficult. In a similar fashion, Pollack and Rossiter (2010, p. 167) advocate analysing social work and argue that we must:

Challenge market rationalities and the ways in which our subjectivities as professionals and clients are organized around these logics and are disciplined in accordance with the neoliberal subject.

Historically, social work in welfare states has been characterised by a struggle between the subjugation and emancipation of clients (Penketh, 2000; Qvarsell, 1993). While such struggles still exist, the space for radical, critical and emancipatory approaches in social work practice seems to be diminishing (Butler \& Drakeford, 2001; Ferguson, 2008; Harlow, Berg, Barry, \& Chandler, 2013; Lauri, 2016; Rogowski, 2010).

While many individuals identify to some degree with their profession, it is often argued that social workers have a strong professional identity and make great use of their selves in their work (cf. Sheppard \& Charles, 2017). Furthermore, social work is arguably a highly political endeavour because of its outspoken purpose of liberation and creating social and economic equality (IFSW, 2014). At the same time, social work may also be considered an endeavour that reproduces the social order and unequal relations of power (Payne, 2016). Such a dual understanding of social work makes an analysis of social workers' subject formation particularly important. If social workers are subjected to governing in ways that shape their subjects in accordance with the needs of contemporary modes of power, it is likely that this will undermine their willingness to criticise and challenge injustice and inequality. Consequently, the aim of this article is to analyse how contemporary neoliberal governing may shape social worker subjects and to deliberate on what this may mean for the relationship and identification with clients, co-workers and management. The questions guiding the analysis are: What subjectification effects may arise from the assemblage of governing analysed? What are the political implications that may follow from such subjectification effects?

\section{Method and data}

This article builds on selected interviews from a previous study (Lauri, 2016) in which 24 in-depth semi-structured interviews were conducted with social workers in six municipalities in Sweden. ${ }^{1}$ The interviews followed five major themes: the reasons for becoming a social worker, their working environment, their degree of influence in their work, conflicts at work and their future as social workers. In this article, twelve out of those 24 interviews are selected for analysis because they provide accounts of the four technologies chosen for this analysis. The selection of technologies was made from the theoretical considerations chosen for this article (see following sections) and suggestions from previous research. The selected twelve interviewees work at eleven different organisations in municipal social services in three different municipalities in two urban regions. The organisational units of their employment range from work with child protective services, adolescents, substance abuse, financial support, disability assistance $\left(\mathrm{LSS}^{2}\right)$ and employment. The interviewees are referred to by pseudonyms.

The fact that the accounts were gathered from a variety of locations and areas of specialisation suggests that their experiences cannot be regarded as either a general tendency in any particular social work specialisation or that they are unique to any one location. It does, however, allow the analysis of experiences from a multitude of sites and settings. Still, the empirical material analysed in this article is limited and the analysis is exploratory. Consequently, the results should not be considered definitive answers but an attempt to point towards indications of potentially problematic governing technologies and their subjectification effects.

\section{An assemblage of governing}

A governmentality approach allows for attention to the wide variety of 'things' at play that enable and mediate the exercise of power (Walters, 2012, p. 62): the assemblage of 'institutions, procedures, 
analyses and reflections, calculations, and tactics' (Foucault, 2007, p. 108). The exertion of power governing - thus refers not only to laws and regulations or command and control operations (Collier \& Ong, 2005, p. 13), but to all sorts of 'arrangements' to meet 'this or that end' (Foucault, 2007 , p. 99). Directing attention to how such arrangements shape subjects to become amenable to governing, a governmentality approach entails an understanding of governing as a practice that far exceeds formal juridical-administrative institutions (Foucault, 1984, p. 64; Walters, 2012, p. 2). This understanding of subjects is based on the assumption that subjects do not exist a priori; they are not an inherent essential quality, but rather the effect of power (Foucault, 1980, p. 98). The deployment of such an assemblage of governing arrangements means that those subjected to them are not always aware of what they are subjected to (Foucault, 2007, p. 105). An important reason for this has to do with the political rationalities embedded in the exertion of this kind of power, those dominant logics embedded in discourse that characterise any given society, which frames the intelligible and sayable (Brown, 2006).

To operationalise my governmentality approach, I use three analytical concepts: rationalities, technologies and effects (Bacchi, 2009). Rationalities focus on the production of knowledge that shapes the understanding of reality and thus affects the knowledgeable; what is understood as reasonable in a particular context. Technologies refer to practical methods, techniques and institutions that enable the governing of human conduct, while effects refer to how human subjects are constituted, shaped and maintained by the interpellation of power. Consequently, the analysis focuses on select rationalities that define problems and make certain practices in social work seem to be logical responses to such problems. The practical arrangements - technologies - used in relation to such rationalities in the context of social work are analysed, along with the subjectification effects this may produce in the encounter between social workers, management and clients. Analysing rationalities and their connection to technologies points to the inseparability of knowledge production and power, i.e. through the truth effects of dominant discourses and the subsequent alignment of what we believe to be true with what benefits the exercise of power (Dean, 2010). As such, a governmentality approach makes possible an inquiry into the interaction between power and knowledge, between self and state regulation and the subsequent legitimisation of power and the social order.

\section{Analysing neoliberal governing assemblages}

Brown (2015) argues that neoliberalism entails the economisation of social relations. The dominance of a neoliberal political rationality means emphasising ideals such as productivity, efficiency and selfsufficiency, which may conflict with and subsequently undermine ideals of quality, equality, care and solidarity (Brown, 2006, p. 694, 2015, p. 10; Dean, 2010). Following this theoretical cue, in the following sections I will analyse two technologies related to economics in contemporary social work: (a) budget governing and (b) individual wage negotiation. Following Foucault's understanding of the intermeshing of power/knowledge, Collier and Ong (2005, p. 12) argue that neoliberal governing assemblages should be analysed in relation to the regulation of knowledge production. For this reason, I have selected two additional technologies for analysis: (c) the client-contractor model (a.k.a. the purchaser-provider split) and (d) so-called social worker supervision, to explore the possible ways in which this may shape the knowing and reflexive social worker.

\section{Budget governing: producing cost-awareness and competition?}

Budget governing is a technology that entails allocating financial resources to separate units within the same social work office, often coinciding with the now widespread specialised organisation of social work according to 'particular' social problems (Grell, Ahmadi, \& Blom, 2013). It also entails giving the manager of each unit individual responsibility for not exceeding the budget. The installation of any technology should be understood as a response to a perceived problem (Bacchi, 2009). Presumably, decentralising fiscal responsibility is founded on a rationality that there is a lack of 
cost-awareness and fiscal prudence in social work and that installing such a technology will generate greater cost-awareness and financial 'care'.

How can this be understood from the perspective of a social worker? Interviewee Olivia tells me that the 'managers protect the budget, because if they can't meet the budgetary target, they're out head-first' and will be replaced by someone fiercer. Such claims have also been reported in an interview study by Astvik (2014), in which managers report that it is common knowledge, although not openly discussed, what happens to a manager who cannot meet their targets: they are out. As budget responsibility is decentralised to mid-level managers, they are given more formal authority to keep costs down, but at the same time they do not have the authority to exceed the budget targets, or even to voice critique, as they seem to run the risk of losing their jobs if they do not comply with the protocol. Whether such a threat is a reality or not, or whether it is common practice to fire managers in this way, is not the scope of this analysis. Rather, the narrative (or knowledge) of such a risk conveyed here illustrates that some social workers experience it as a fact, which may work as a way to make understandable and legitimise an austerity scheme, thus producing acceptance and functioning as a tool of self-governing.

Decentralising the responsibility for scarce resources may also produce competition. Interviewee Emma tells me that:

The colleague I was supposed to make the house call with had to commit the child since the mother turns out to be homeless because of a denial from another division of the social services of her application for housing.

The demand for each unit to tend to its own budget may hamper cooperation between the different social work units and undermine a holistic approach to clients' needs. Interviewee Gabriel, who works with clients struggling with substance abuse, tells me that:

\begin{abstract}
Every unit, every manager has, which I can understand, a responsibility for their budget. But that leads to financial austerity [...] [and] a lot of discussions about who is supposed to pay. We have two managers with their separate little budgets [...] so it becomes unwieldy because you can't get those things to work, quite simple matters really. We deal with treatment, treatment facilities and such. Then maybe these people need a place to stay during the assessment. Then it's financial support who's supposed to take care of that, to approve it. If they don't, or if things don't work out, and they have no housing for a week or so before treatment, they abscond. They have a relapse and they're gone.
\end{abstract}

The conflict over 'who is supposed to pay' makes social work more complicated and may force social workers to care more about financial matters than clients. Narrow frames for spending, decentralised budget responsibility and punishment for exceeding budgets may thus generate a conflictual and competitive working environment within which each unit is shaped to 'mind its own business'. This may produce compliance in an austerity scheme, but arguably it also undermines the willingness of mid-level managers to voice critique. As the cost-awareness produced by budget governing trickles down to the individual social worker due to their proximity to managerial authority, it may become part of common-sense discourse about social work. Interviewee Felicia responds to a question about her ability to make individual decisions on treatment:

\footnotetext{
And then she [the manager] said, 'but hold it now,' like, 'how did you reason here?' like 'no, this is too much' or 'it costs too much' so in that case you might have to back off a bit. [...] Yes, we know more, so she trusts our appraisal on most of the cases. However, she might question it from, like, cost and that we should think about not having, oh, what is it she says ..., LEON ${ }^{3}$ I think: lowest effective level of care. It's something she learned on some kind of course, and it's pretty good to think like that. I don't know the complete philosophy behind it, but, but, that we should not take care of, I mean, care for people more than they need.
}

Although Felicia says that the manager admits to her knowing more about the case and about social work, the manager nevertheless alludes to the rationality of cost-awareness and of not providing more expensive care than a client needs. What a client needs, however, does not necessarily have a fixed answer; rather, it is dependent on context, dominant forms of knowledge and political priorities. From the rationality expressed by Felicia, it seems as though cost-awareness can shape the assessment of needs in a way that makes cheaper alternatives and limits to support seem reasonable. 
One way of handling the conflicts that may arise from having your assessment overruled by management is to allude to a rationality of individual responsibility. Felicia tells me that an old man ...

... wanted to stay home and take 'time off' from rehab, where he is right now. And I didn't agree that he should because a week ago he drank when he stayed home. [...] eventually I felt like, why should I sit here and, like, he's a grown man, he's twice as old as I am, and he can choose for himself really. [...] instead, he should be held responsible for his own actions. At the same time, I have to explain to him that we're paying for this, you can't just go home and do what you want; in that case, you'll have to declare that you don't want the treatment anymore and, like, leave.

Although she argues that there is a risk of relapse if this client takes time off from rehab, Felicia also expresses the rationality of choice, individual responsibility and cost-awareness. It seems that the rationality displayed here says: you cannot go home because we are paying for your treatment; if you intend to have a relapse, be responsible about it, tell us right away and renounce your place on the programme.

A rationality by which fiscal matters seem to override matters of care is something that interviewee Nora also tells me about.

Staying sober and off drugs, maybe even improved housing, and feeling better, that's a positive result to me, but when you read the meeting documents then it's all about the budget. The budget is in balance, then it's like 'who cares what happens to the clients?'

Nora is referring to management's talk about positive results in staff meetings, where the attention to the budget being in balance seems to have given the term 'positive results' a distorted meaning. On a similar topic, interviewee Beatrice tells me that in her municipality the management introduced a zero-sum game to remedy their budget deficit. This meant 'No new commitment of care for children may be initiated until another is finished, so that money may be released.' and Beatrice says: 'it's completely sick!' and dishonouring the 'claim to work in the best interests of the child or from individual assessments'.

These selected examples suggest that budget governing augments a focus on financial prudence and cost-awareness and that this may produce internal competition over resources and hamper a holistic and careful approach to clients. Such a governing technology may escape critique from managers due to the imminent threat of losing one's job (whether factual or not) and a common-sense rationality of cost-awareness. Budget governing is thus a technology that can lead to the prioritisation of fidelity to budget targets at risk of overriding other rationalities of resource allocation and attention, such as clients' needs or quality of support and care (Schrøder, 2014). Competition between units may also divide social workers and undermine the formation of a subject that is oriented towards a collective. In addition, it is also a technology that may allow local politicians to escape criticism by decentralising the delicate decisions about how to prioritise scarce resources to mid-level managers (Astvik, 2014).

\section{Individual salaries: producing individual performance and submission?}

Within several professions in Sweden, there is a long tradition of collective bargaining over salaries. Under such a system, salaries are typically negotiated between central union representatives and employer organisations, or the local union and the employer. However, over the past couple of decades, more and more employers have introduced individual negotiations over wages, sometimes with the connivance of unions. The extent to which such a technology is widespread in Swedish social work is not the scope of this analysis; rather, I intend to deliberate upon the possible effects it may produce in terms of shaping social workers subjects. Individual salaries arguably allude to a market rationality of performance and competition, under which individual financial rewards are expected to encourage workers to strive for improvement and perfection in their performance. The installation of such a technology should be understood as a response to a perceived problem of lack of efficiency in production, as any policy is a response that originates in a particular but 
seldom explicitly voiced representation of a problem (Bacchi, 2009). While the empirical support for enhanced performance is slim (Lapidus, 2015; Nilsson \& Ryman, 2005), the technology of individual negotiation for wages may have other effects. Interviewee Rosa argues that your salary is dependent on your obedience and believes that it is a practice installed to divide and conquer. From word of mouth, she has been told that giving 'upwards-nudges' of affirmation to the management and 'being nice' have been included in the formal criteria for wage negotiation at her workplace. She reflects: 'Being nice!? What the hell does that mean?' What is meant by being nice is not clear, but Rosa is outraged over what I interpret as a demand to be 'civilised' and to avoid direct criticism of management. Rather, positive affirmation is encouraged. Another interviewee, Ylva, elaborates on the reasons behind the culture of silence at her workplace:

This thing with individual salaries and that it's more and more about your individual performance, and that's about being loyal to the manager. [...] And I was told that I couldn't have more of a raise because I wasn't loyal to the operation.

According to Ylva, the negotiation of individual salaries is a practice that produces loyalty to management by stifling protest - a culture of silence. She had been told by her manager that voicing opinions about strenuous working conditions at staff meetings created unrest and harmed her co-workers and that this was an expression of disloyalty. Olivia has a similar experience:

If you sit and whine during coffee and say that you have too much to do, you induce a bad atmosphere. It doesn't support an increased wage.

Not only may individual negotiations for salary produce a performance-oriented subject, as Olivia, Rosa and Ylva have argued, it may also stifle critique and enhance loyalty to management. In their study of social workers, Astvik, Melin, and Allvin (2014) met similar experiences. Those who protest say they are seen as troublemakers and that they have internalised a sense of being a tiresome burden to others (Astvik et al., 2014, p. 59). In addition, Ylva argues that individual salaries create an atmosphere of secrecy and says: 'Now, no one wants to disclose to others what they earn'. Lapidus (2015) points to a similar tendency and argues that individual wages may undermine workers' solidarity and cohesion (see Nilsson \& Ryman, 2005 for an overview and similar conclusions).

Individual salaries are thus arguably a governing technology that is based on a notion - or problem representation - that workers are performing below their potential. The installation of individual salaries thus alludes to a rationality of individual salaries $\rightarrow$ competition between individuals $\rightarrow$ enhanced individual performance, i.e. a technology that produces competing individuals who strive to display their individual performance. Because performance is linked to wage negotiations with management, it is likely to be oriented towards the priorities of management and displayed accordingly, rather than towards peers or clients. As argued above, this may also be interpreted as a technology for stifling social workers' protest by shaping subjects loyal to management, which may undermine the formation of a critical and collectively oriented social worker subject.

\section{Client-contractor model: producing a competitive and distant knower?}

The client-contractor model (a.k.a. purchaser-provider split) is a business model introduced into the organisation of welfare provision in order to produce market-like competition between care providers. Its basic principle is to separate the work of assessment and 'purchase' from social work provision (Gleghorn, 1995). This technology is arguably based on a rationality that public service is somehow defective in terms of production and that the installation of this approach will increase efficiency and flexibility and improve quality (Gleeson \& Knights, 2006; Jacobsson, 2002; Ranson, 2003). Regardless of whether such promises hold true or not, Rosa tells me what this division of labour has meant for her:

I'm becoming more or less an administrative clerk. The idea is to make quick assessments, approve some kind of treatment. We're not supposed to engage with clients. That's the idea. 
This division of labour means that social workers in municipal social services primarily engage in the assessment of clients but not in their further counselling or treatment, which is carried out by external providers, either municipal or private. Tina, who works in another organisation with this division of labour, says that her work primarily entails 'handling invoices, making contracts, you're so far away from contact with [clients]'.

These accounts suggest that, for those who work in the social services, the client-contractor model has reduced the time spent with clients. Social worker Donna ${ }^{4}$ describes her experience in the following terms:

The social services are divided into 'client' and 'contractor' [...] A thorough work for change, however, demands continuous contact, something which a social worker does not have the time for.

According to Donna, the reduced time spent with clients undermines a thorough work for change because such work demands continuous contact. This is an effect that has been highlighted elsewhere; for example, Gleghorn (1995) argues that such a model has problems dealing with the complexity of social problems and also points to effects like the fragmentation of social work, inflexibility and superficial assessments. Following an evaluation of the implementation of a client-contractor model in a Swedish municipality, Billquist and Gustafsson $(2002$, p. 9) put it bluntly: 'it was not good for anyone'.

Regardless of whether this technology actually produces efficiency, flexibility or higher quality (which seems unlikely), I want to concentrate on the alterations in the forms of interaction between social worker and client and how this may affect knowledge production. Witnessing the predicament of the client at first hand places a social worker in an ideal position to understand the effects of political and social structures, argue Daniel and Wheeler (1989). Similar arguments have been put forward for understanding the critical and structural approach to social problems that developed in the British and North American settlement movements in the late nineteenth century. It is believed that it was due to their proximity to suffering (they lived in community houses with their 'clients') that such knowledge about social problems was produced (Hugman, 2009; Pettersson, 2001). Interviewee Ylva ponders the effects of this practice:

The social worker ends up further and further away from the client and then you can no longer see the individual, and that makes it easier to make those difficult decisions [...] because you can't see their suffering.

Arguing that the client contractor model makes it harder to 'see' the individual is something I interpret as a loss of the basis for complex knowledge production that can develop from witnessing suffering and injustice up close. Ylva argues that the distance produced by this practice makes it easier to make difficult decisions. This suggests that the technology of separating those who decide upon the allocation of public resources from clients makes austerity easier to implement because it produces a more distant and detached social worker subject. Such a method of organising work may shape social workers into less 'caring' subjects, which arguably makes it less discomforting to condition, reduce or deny claims for support. In fact, Olivia tells me, 'once a manager told me that this is the purpose of dividing us into clients and contractors!'

Similarly to budget governing, research also suggests that the client-contractor model produces competition for resources within the organisation (Jacobsson, 2002), and Lundström's (2011) research on Australian social work suggests that this model gave management an opportunity to hire less qualified labour for the assessment of clients' needs because they made less of a 'fuss'.

The accounts of Rosa, Tina, Donna, Ylva and Olivia taken together suggest that knowledge production founded upon both the social work profession and proximity to clients' suffering are important for understanding clients' predicaments and their origins. To determine the extent of this technology in Swedish social work, or whether it is increasing, is not the scope of this analysis. Rather, it is about highlighting the potential subjectification effects that may emerge from a client-contractor model. Although the empirical material is limited, in light of the analytical framework and other research into the matter, I would argue that reducing the time spent with clients 
and cultivating a culture of competition may shape a social worker subject who knows less, and therefore may care less, about clients' complex problems. There is also a risk that this may undermine the formation of a critical social worker subject and, due to the fragmentation of work, the sense of constituting a collective of social workers.

\section{Regimentation of individual supervision: disciplining a reflexive subject?}

Individual supervision for social workers is a long-standing tradition in social work (Kadushin \& Harkness, 2014). In a Swedish context, its most common expression entails a practice in which the social worker sees an external counsellor for the purpose of unburdening and self-reflection and it is highly cherished by social workers (Höjer, Beijer, \& Wissö, 2007). The shape and content of this supervision has largely been defined by the profession and is often characterised by long-term commitment and a psychoanalytical approach (Payne, 1994).

Previous surveys suggest that a majority of Swedish social workers are offered supervision, although there may be signs of a gradual decline (Höjer et al., 2007; Vision, 2013). Previous studies have suggested that managers rarely intervene in the content or aim of this supervision (Egelund \& Kvilhaug, 2001), but in my interviews, I have found examples that suggest something different. Tina told me:
Tina: $\quad$ The supervision is strictly about legal aspects.
Interviewer: You mean the supervision you're getting, is about ...
Tina: $\quad$ Yes, legal matters.
Interviewer: Okay, I was under the assumption that supervision was like a kind of, to relieve the socially bur- dening aspects of being a social worker, sort of. Isn't that what it's meant to be?
Tina: Yes, that's what it's supposed to be, and I believe that's what is has been, and then we had a period of no counselling at all and now it's with a juridical consultant. Like, on legal matters.

Tina has experience of social work supervision undergoing changes. In her case, it has manifested as the shift from a free modus of reflection to supervision on legal matters. Another interviewee, Simon, told me that his supervision had been altered as well. At his workplace, he was used to choosing the counsellor who performed the supervision, but recently management had decided to change this and engaged counsellors who were not psychotherapists, but rather counsellors who use CBT and behavioural analysis instead of a psychoanalytical approach. 'She [the manager] just decided, we were not allowed to take part in it. [...] this is worthless, it's not counselling.' As opposed to a psychoanalytical approach, CBT focuses more on the present and, according to Binkley (2011), its popularity comes not only from an understanding that 'it works' and that it is cheaper, but also because it alludes to the idea that mental health is the result of individual cognitive attitudes. Binkley argues that CBT fits well into a happiness discourse, which helps to shape individual subjects as responsible for constant self-control and self-improvement (see Ahmed, 2010 for similar conclusions).

Tina also told me of a previous experience when she worked at financial support:

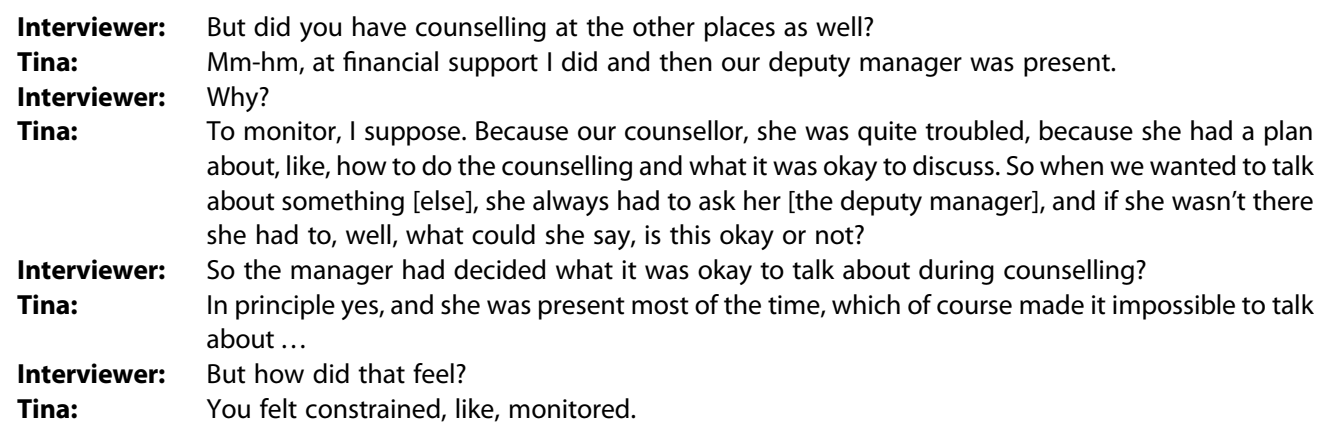


The few examples presented here suggest a particular interest from management in social workers' supervision. Deciding who does the supervision, with what theoretical approach and what is allowed to be talked about seems like a desire to manage the reflections and emotions that arise from engaging in contemporary social work. In their survey, Höjer et al. (2007) concluded that supervision is highly cherished and intensely defended by social workers but, similarly to the quotes above, there were reports of management intervention. Others reported that their supervision was terminated altogether, officially for reasons of austerity. Yet others reported that management had changed their supervision from external to internal, which was assumed to restrict the space for critical reflection and discussion. This was due to internal supervision often being performed by members of the management as opposed to external supervisors who are not directly employed by the organisation and thus have no formal ties with it (Höjer et al., 2007).

In light of such accounts, and in connection with previous sections on management efforts to stifle protest via economic sanctions and rewards, the examples of management's attempts to control supervision presented above may be understood as an effort to manage dissatisfaction among social workers. Whether this should be understood as a technology to handle rising discontent in an era of neoliberal austerity is not possible to discern from such a limited sample. However, I would argue that, if social workers are given a sanctuary space to reflect on any kind of displeasure, this may very well spur the formation of a critical subject. Given the rising discontent with the developments in social work during the last couple of decades, it is not unlikely that a need has developed for new technologies to handle this (Lauri, 2016). Controlling supervision by having managers present, by restricting the topics allowed for discussion and by focusing on CBT, 'superficial' matters may arguably be an attempt to undermine the formation of a wilful and critical social worker subject and produce an understanding that the key to their grievances can be found in themselves.

\section{Concluding discussion}

From my analysis of the four technologies above: budget governing, individual wage negotiation, the client-contractor model and social worker supervision, I suggest that they may be seen as a neoliberal governing assemblage with the ability to shape social workers into individualised, competitive and detached subjects. Interviewee Maude sums up the developments she has witnessed:

Many of us feel bad, we're stressed [...], and the atmosphere in the group is deteriorating, and we also have a high personnel turnover. Then it's easy to start guarding your own because we all have so much to do, so you're, like, well it all divides us, and people lose the energy to engage in trying to improve things or engage with the union, because the only thing that you're occupied with is your cases and keeping your head above water.

The analysis and this quote from Maude suggest that, under current conditions, the interviewed social workers become detached from both peers and clients and instead tend to become loyal to their rationalised selves and to management - minding their own business. Olivia deliberates on her long experience of social work and explicitly says that she 'mourns the [loss of] collegiality' and Emma, who has only been working for a couple of years, says she will quit in the near future because 'under these circumstances' she's afraid she will 'become an unsympathetic person.' It seems as though she is afraid of what she will turn into (i.e. how her subject will be altered) as a result of working under current conditions.

An effect that may arise from detachment towards clients is that it obscures the context of which any individual is part, which makes it easier to embrace a neoliberal discourse of austerity and individual responsibility and to understand clients' predicaments as the result of poor choices (Bauman, 1998; Brown, 2015; Garrett, 2010; Wacquant, 2009).

Loyalty to management seems to be further augmented by punishing protest and rewarding silent performance. The conflict between protest and loyalty to management is not a new one. However, the particular rationalities and technologies examined here arguably display unique 
qualities that may be assigned to contemporary neoliberalism. This suggests that an individualised culture of silence may be established through such neoliberal governing assemblages, which is likely to hamper the formation of a critical social worker subject. While Rosanvallon (2008) argues that contestation and protest over perceived inequalities are fundamental to achieving change, Rancière (2006) proposes understanding democracy as a process rather than a condition. From such a perspective, criticism and protest against perceived injustices and those who exercise power is essential for the development of democracy. Brown (2015) argues that the market logics and individualisation that constitute the political rationality of neoliberalism make it difficult for citizens to establish a collective political subject, which leaves limited space for citizens to unite into a demos. If this is indeed true for social work, the analysis suggests that the process of shaping social workers into individualised, competitive and detached subjects, silent and loyal to management, has serious effects. It suggests that the formation of a critical collective social worker subject willing to protest against inequality and injustice is undermined.

While my interviews suggest that neoliberal governing assemblages may have the effect of producing such submission and compliance, for some of those who have uncovered and called out such a scheme, it has produced awareness and resistance outside of the traditional arenas of the workplace and unions. They have shared with me stories about their activist work in 'clandestine' networks that cut across union membership and social service offices and about their efforts to escape the surveillance and repression of current governing assemblages. This suggests that, although neoliberal governing assemblages may have problematic subjectification effects, they are not an allengulfing and flawless machine. Hardt and Negri (2004) argue that a collective subjectivity can develop in radical spaces by challenging structures of power and, indeed, some of the critical accounts in this analysis suggest that some social workers respond to neoliberal governing assemblages by developing new techniques and collective subjects of resistance. Let us hope they will persist.

\section{Notes}

1. The strategy for selection was strategic. I wanted to gather accounts from a wide variety of sites and organisational settings, and I used several approaches to find respondents, such as contacting unions and management in the social services in different parts of the country, through national social worker networks and personal acquaintances. The interviews were recorded and transcribed between 2012 and 2015.

2. Law on support for disabled people.

3. LEON refers to the management rationality 'lowest level of effective care' used in some contexts like the Norwegian healthcare services (Holm, Mathisen, Sæterstrand, \& Brinchmann, 2017).

4. This quote is from a social worker whom I interviewed but collected from a post on the website of a network of critical social workers (Nu bryter vi tystnaden, 2015).

\section{Acknowledgments}

I wish to thank the interviewees for sharing their thoughts and critiques on this matter.

\section{Disclosure statement}

No potential conflict of interest was reported by the author.

\section{Notes on contributor}

Marcus Lauri, PhD political science, is a lecturer at the Department of Social Work, Mid Sweden University. His dissertation analyses the governing of social work in order to understand contemporary protests from social workers concerning increasing workloads, de-professionalisation and alienation. Lauri has also conducted research on suburban riots, racist discourse in professional equal rights work (with teachers and union representatives) and in public discourse on men's violence against women. He is currently working on two projects: one concerning the shaping of responsible 
subjects through the counselling method of motivational interviewing (MI) in the context of men's violence against women, and the other on the commodification of knowledge in commercial gender equality consultancies in Swedish public services.

\section{ORCID}

Marcus Lauri (D) http://orcid.org/0000-0002-3620-7105

\section{References}

Ahmed, S. (2010). The promise of happiness. Durham, NC: Duke University Press.

Astvik, W. (2014). Lojal, lydig och tyst: Om nya styrsystem, decentraliserat ansvar och bristfällig dialog i socialtjänsten konferensen. Välfärd och Framtid på ABF i Stockholm 15-16 mars 2014. Stockholm: Nu Bryter Vi Tystnaden.

Astvik, W., Melin, M., \& Allvin, M. (2014). Survival strategies in social work: A study of how coping strategies affect service quality, professionalism and employee health. Nordic Social Work Research, 4(1), 52-66.

Bacchi, C. L. (2009). Analysing policy: What's the problem represented to be? Frenchs Forest: Pearson.

Bauman, Z. (1998). Work, consumerism and the new poor. Buckingham: Open University Press.

Billquist, L., \& Gustafsson, G. (2002). En oreflekterad omorganisation. Socionomens forsknignssupplement nr 14. Socionomen, 8(14), 1-10.

Binkley, S. (2011). Happiness, positive psychology and the program of neoliberal governmentality. Subjectivity, 4(3), 371394.

Brown, W. (2006). American nightmare: Neoliberalism, neoconservatism and de-democratization. Political Theory, 34(6), 690-714.

Brown, W. (2015). Undoing the demos: Neoliberalism's stealth revolution (1st ed.). New York, NY: Zone Books.

Butler, I., \& Drakeford, M. (2001). Which Blair project? Communitarianism, social authoritarianism and social work. Journal of Social Work, 1(7), 7-19.

Collier, S. J., \& Ong, A. (2005). Global assemblages, anthropological problems. In A. Ong \& S. J. Collier (Eds.), Global assemblages: Technology, politics, and ethics as anthropological problems (pp. 3-21). Malden, MA: Blackwell Publishing.

Daniel, P., \& Wheeler, J. (1989). Social work and local politics. London: Macmillan Education and British Association of Social Workers.

Dean, M. (2010). Governmentality: Power and rule in modern society (2nd ed.). Thousand Oaks, CA: Sage.

Egelund, T., \& Kvilhaug, A. (2001). Supervisionens organisering. Socialvetenskaplig Tidskrift, 3, 180-198.

Ferguson, I. (2008). Reclaiming social work: Challenging neo-liberalism and promoting social justice. Los Angeles, CA: Sage.

Foucault, M. (1980). Power/knowledge: Selected interviews and other writings 1972-1977 (1st American ed.). New York, NY: Pantheon.

Foucault, M. (1984). The Foucault reader. New York, NY: Pantheon Books.

Foucault, M. (2007). Security, territory, population: lectures at the collège de France, 1977-1978. New York, NY: Picador.

Garrett, P. M. (2010). Examining the 'conservative revolution': Neoliberalism and social work education. Social Work Education, 29(4), 340-355.

Gleeson, D., \& Knights, D. (2006). Challenging dualism: Public professionalism in 'troubled' times. Sociology, 40(2), 277295.

Gleghorn, M. (1995). Service disputes cause bad publicity and loss of trust. Professional Social Work, 2(12), 6.

Grell, P., Ahmadi, N., \& Blom, B. (2013). Hur inverkar organisationsstrukturen på socialtjänstens klientarbete?: en sammanfattning av kunskapsläget. Socialvetenskaplig tidskrift, 20(3-4), 222-240.

Hardt, M., \& Negri, A. (2004). Multitude. New York, NY: Penguin Press.

Harlow, E., Berg, E., Barry, J., \& Chandler, J. (2013). Neoliberalism, managerialism and the reconfiguring of social work in Sweden and the United Kingdom. Organization, 20(4), 534-550.

Holm, S. G., Mathisen, T. A., Sæterstrand, T. M., \& Brinchmann, B. S. (2017). Allocation of home care services by municipalities in Norway: A document analysis. BMC Health Services Research, 17(1), 1-10.

Höjer, S., Beijer, E., \& Wissö, T. (2007). Varför handledning?: handledning som professionellt projekt och organisatoriskt verktyg inom handikappomsorg och individ och familjeomsorg. Göteborg: FoU i Väst.

Hugman, R. (2009). But is it social work? Some reflections on mistaken identities. British Journal of Social Work, 39(6), 1138-1153.

International Federation of Social Work. (2014). Global definition of the social work profession. Retrieved from http://ifsw. org/get-involved/global-definition-of-social-work/

Jacobsson, B. (Ed.). (2002). Organisationsexperiment $i$ kommuner och landsting. Stockholm: Santérus.

Kadushin, A., \& Harkness, D. (2014). Supervision in social work (5th ed.). New York, NY: Columbia University Press.

Kamali, M., \& Jönsson, J. H. (Eds.). (2018). Neoliberalism, Nordic welfare states and social work: Current and future challenges. London: Routledge. 
Lapidus, J. (2015). Social democracy and the Swedish welfare model: Ideational analyses of attitudes towards competition, individualization, privatization (Dissertation). Göteborgs universitet, Göteborg.

Lauri, M. (2016). Narratives of governing: Rationalization, responsibility and resistance in social work (Dissertation). Umeå universitet, Umeå.

Lundström, T. (2011). Om senmodernitet, riskbedömningar och social barnavård. In I. Höjer \& S. Höjer (Eds.), Familj, vardagsliv och modernitet (pp. 101-114). Göteborg: Göteborgs universitet/Institutionen för socialt arbete.

Nilsson, T., \& Ryman, A. (2005). Individuell lön - lönar det sig?: fakta och tro om individuell lönesättning. Stockholm: Arbetslivsinstitutet.

Nu bryter vi tystnaden. (2015, January 25). Veckans brott: Utredare, inte socialarbetare. Retrieved from https://nbvt. wordpress.com/2015/01/25/veckans-brott-utreda-och-administrera-framfor/

Oksala, J. (2013). Feminism and neoliberal governmentality. Foucault Studies, 16, 32-53.

Payne, M. (1994). Personal supervision in social work. In A. Connor \& S. Black (Eds.), Performance review and quality in social care (pp. 43-58). London: Jessica Kingsley.

Payne, M. (2016). Modern social work theory (4th ed.). New York, NY: Oxford University Press.

Penketh, L. (2000). Tackling institutional racism: Anti-racist policies and social work education and training. Bristol: Policy.

Pettersson, U. (2001). Socialt arbete, politik och professionalisering: den historiska utvecklingen i USA och Sverige. Stockholm: Natur och kultur.

Pollack, S., \& Rossiter, A. (2010). Neoliberalism and the entrepreneurial subject: Implications for feminism and social work. Canadian Social Work Review, 27(2), 155-169.

Qvarsell, R. (1993). Skall jag taga vara på min broder?: tolv artiklar om vårdens, omsorgens och det sociala arbetets historia. Umeå: Institutionen för idéhistoria, Univ.

Rancière, J. (2006). Hatred of democracy. London: Verso.

Ranson, S. (2003). Public accountability in the age of neo-liberal governance. Journal of Education Policy, 18(5), 459-480.

Rogowski, S. (2010). Social work, the rise and fall of a profession. Bristol: Policy Press.

Rosanvallon, P. (2008). Counter-democracy: Politics in the age of distrust. Cambridge: Cambridge University Press.

Schrøder, I. M. (2014). Budgetblikket i socialt arbejde med udsatte børn og unge. Frederiksberg: Professionshøjskolen Metropol/Institut for Socialt Arbejde.

Sheppard, M., \& Charles, M. (2017). Personality in those entering social work training in England: Comparing women and men. European Journal of Social Work, 20(2), 288-296.

Vision. (2013). Stolthet och profession: En rapport om arbetsvillkoren för socialsekreterare och biståndshandläggare $i$ socialtjänsten. Stockholm: Author.

Wacquant, L. J. D. (2009). Prisons of poverty (Expanded ed.). Minneapolis: University of Minnesota Press.

Walters, W. (2012). Governmentality: Critical encounters. London: Routledge. 